\title{
Use of a nurse with advanced practice in chronic wound management
}

\author{
${ }^{1}$ Vysoká škola zdravotníctva a sociálnej práce sv. Alžbety, Bratislava, n.o., PhD. student, Slovak Republic \\ ${ }^{2}$ Prešovská univerzita v Prešove, Fakulta zdravotníckych odborov, Katedra ošetrovatel'stva, Slovak Republic \\ ivana.ronayova@gmail.com, beata.gress.halasz@unipo.sk
}

\author{
Ронайова І., Грешш Галасз Б. \\ Можливості реалізації \\ практики лікування хронічних ран \\ для медичних сестер зі значним досвідом
}

\author{
Ронайова И., Грешш Галасз Б. \\ Возможности реализации \\ практики лечения хронических ран \\ для медицинских сестер со значительным опытом
}

\section{Objective}

Chronic, non-healing, or difficult-to-heal wounds cause significant health burdens which can be not only economic for health systems, but also physical, emotional, and social for the patient. Comprehensive wound care can vary widely due to differences or the absence of standardized procedures, and lead to insufficient enforcement of evidence-based practice [1]. The competencies of a nurse consist in the management of chronic wounds.

In connection with the new legislation expanding the competencies of nurses at the level of advanced practice [2], our intention is to approach the possibilities of applying such a role in a specific area of focus - chronic wound management.

Educational institutions in the USA have been offering certification training for nurses in wound management (,Wound Care“ or ,Wound Management") and for nurses with advanced experience - APRN (Advanced Practice Registered Nurses) [3] since 2012. Educational institutions in countries such as the United Kingdom, Wales and Ireland have a separate wound management nursing department called „Tissue Viability Nursing“ or „Wound Management“ [4]. Education takes place at various levels with a postgraduate certificate, diploma, or with a master's degree „Masters in Wound Healing and Tissue Repair" [4,5]. The competencies of certified nurses in wound management include, in particular, wound debridement, removal of biofilm from the wound bed, cleaning and application of wet wound healing materials, assessment, monitoring and evaluation. As a key member of the multidisciplinary team, the nurse coordinates patient wound care. They often work with patients with stoma, diabetic legs, pressure ulcers, forearm ulcers and other chronic, hardly healing or non-healing wounds, in the context of holism and bio-psycho-social and spiritual needs. Wound management certified nurses solve problems with incontinence and its complications, surgical infections, but also other wounds, they order dressing material, perform diagnostic tests, apply innovative bioengineering products, etc. Nurses provide education to patients and their caregivers on the following topics: how to take care of the wounds, how to prevent recurrence or worsening of chronic wounds, and how to prevent infections and other complications, and so on [6].

A nurse with advanced experience in wound management has, among other competencies, the task of acting as a "case manager", educator and mentor [7]. In Slovakia, according to the current legislation, there is an educational program in the certified work activity "Nursing care for chronic wounds" [8]. In January 2020, a minimum standard was issued for this certified program [9].

The aim of the research is to map the interest in certification studies in chronic wound management for nurses, to find out whether a nurse with a certificate in chronic wound management is desirable from the view of management to create a job position, and to find out how management perceives legislative and working conditions of independent practice in the profession of nurse in the management of chronic wounds in the context of advanced practice in nursing.

\section{Design}

Quantitative exploratory descriprive design.

\section{Participants}

The research group consisted of 48 nurses with advanced practice who work as managers working in institutionalized or community-based healthcare and take care of the patients with chronic, non-healing, or difficult-to-heal wounds The selection criteria were at least 5 years of experience in the field of wound management and managerial position (head nurse, section nurse, guarantor in ADOS Home Nursing Care Agency).

\section{Methods}

For data collection, we chose a measuring instrument of our own design. The measurement tool consisted of demographic and categorical variables, and questions focused on the activities of nurses with advanced experience in wound management (independent assessment and treatment of skin 
integrity disorders, prescription of medical devices by the nurse, evidence-based research $(\mathrm{EBN})$, education and communication with patients, certification study). To evaluate the points of the questionnaire, we used the Likert scale of perception from 1 (negative) to 7 (positive).

The questionnaire was processed into an online version using the Survio software, which was distributed through the SKSaPA (Slovak Chamber of Nurses and Midwives) portal with the consent of the Chamber in January 2019.

The measuring instrument showed a reliability of Cronbach $\alpha=0.937$, which we evaluate as a high reliability of the instrument. The data were processed with the program SPSS 25.0 and we used descriptive and inductive statistics for evaluation.

\section{Results}

The average age of the respondents was $43(\mathrm{SD} \pm 8.72)$ years and $20(\mathrm{SD} \pm 10.36)$ years of practice. The group consisted of female nurses, managers working in different types of departments in the institutionalized area, and nurses working in the community area, with different frequencies in the implementation of comprehensive nursing care for chronic wounds. An overview of the file characteristics is listed in Table 1. A large group consisted of managers in the institutionalized area $(66.7 \% ; n=32)$, in the field of surgery
(45.8\%; $\mathrm{n}=22$ ), and most managers held a license for independent practice $(37.5 \% ; \mathrm{n}=18)$.

Based on the points in the questionnaire, we evaluated statistical parameters focused on the perception of comprehensive nursing care management related to the treatment of chronic, non-healing wounds in managers in the institutionalized or community area, where the average response was positive and highest $(\mathrm{M}=5.86)$ of all findings. We also found out a positive interest in education in a certification study in chronic wound management with the second highest average $(M=4.59)$. Our findings also show that management perceives positive legislative and working conditions for the performance of independent practice in the profession of nurse in wound management $(\mathrm{M}=4.52)$. The individual answers show a positive interest in cooperating in consultations with a nurse with a certificate in the field of wound management by management $(\mathrm{M}=4.22)$, and an interest in creating such a job position $(M=4.20)$. The analysis of data from the supplementary items of the questionnaire testifies to the respondents' concerns about not concluding contracts with insurance companies within the reporting of work activities, which represented $32.5 \% \quad(\mathrm{n}=16)$ representation, and reluctance and distrust of the public (patients) towards a certified nurse in wound management which represented $15.5 \%(n=6)$ representation.

Table 1. Characteristics of the set of respondents $(n=48)$

\begin{tabular}{|c|c|c|}
\hline & $\mathbf{n}$ & $\%$ \\
\hline \multicolumn{3}{|l|}{ Job Area } \\
\hline manager in the institutionalized field of healthcare & 32 & 66,7 \\
\hline Community Health Care Manager (ADOS) & 16 & 33,3 \\
\hline \multicolumn{3}{|l|}{ Work Place } \\
\hline intern & 13 & 27,1 \\
\hline surgery & 22 & 45,8 \\
\hline Home nursing care (ADOS) & 13 & 27,1 \\
\hline \multicolumn{3}{|c|}{ Type of license in the profession of nurse } \\
\hline to perform the activity of a professional representative & 13 & 27,1 \\
\hline to perform independent practice & 18 & 37,5 \\
\hline to perform medical profession & 10 & 20,9 \\
\hline without license & 7 & 14,5 \\
\hline
\end{tabular}

Table 2. Areas of perception of nurses $(n=48)$

\begin{tabular}{|c|c|}
\hline Area of perception & M (SD) \\
\hline comprehensive management of nursing care for chronic wounds & $5,86 \pm 1,22$ \\
\hline interest in education in certification studies & $4,59 \pm 1,97$ \\
\hline interest in cooperation with a certified nurse (consultations) & $4,22 \pm 2,10$ \\
\hline interest in creating a job position in the "morning team" (job description) & $4,20 \pm 1,93$ \\
\hline $\begin{array}{l}\text { the application of the nurse to provide independent nursing practice on the basis of valid legislation } \\
\text { within the scope of competencies }\end{array}$ & $4,52 \pm 1,93$ \\
\hline
\end{tabular}

Subsequently, we investigated whether there are significant differences in the perception of management in the field of wound management and the type of workplace (internal, surgery, ADOS), the area of the job position (institutionalized and community) and the type of license (Table 3). We found significant differences within the type of 
workplace, where we found a higher perception in the field of wound management among nurse managers working in ADOS compared to nurse managers working in internal medicine departments.

There was a significant difference between nurses in the position of community health manager (ADOS) and nurse managers in the institutionalized field of healthcare. We found a significant difference in perception between nurses-managers with different types of licenses, where we can state that nurses licensed to perform the activities of a professional representative in the profession of nurse (ADOS guarantor) reported a higher perception of wound management by nurses with advanced experience than nurses-managers without license. We assume that this is related to the completion of the specialized study "Nursing care in the community", where the nurse performs specialized activities in comprehensive nursing care for people in communities in the relevant catchment area and respects the specifics of care with respect to geographical area and age group. The range of practical activities, skills and experience in a given specialization study includes medical services, such as wound care, ostomy treatment, drainage treatment, use of assessment and measurement scales in the field of wound assessment, etc.

\section{Table 3. Statistical testing between specified variables}

\begin{tabular}{|l|c|c|c|}
\hline \multicolumn{1}{|c|}{ Vzt'ah } & Test & Hodnota & P \\
\hline perception vs. type of workplace / dept. & & 15,161 & $0,034^{*}$ \\
\hline perception vs. job area & Kruskal-Wallis & 23,295 & $0,000 * * *$ \\
\hline perception vs. license type & & 8,816 & $0,032 *$ \\
\hline * p - hodnota štatistickej významnosti *p<0,05; $* * \mathrm{p}<0,01 ; * * * \mathrm{p}<0,001$ & & \\
\hline
\end{tabular}

\section{Discussion}

In the research, we focused on the example from abroad to find out the interest of management in a certified nurse with advanced experience in wound management. Abroad, these nurses are referred to as "Wound Care Nurse", "Wound Management Nurse", "Tissue Viability Nurse" or "Wound Management Nurse", where the condition for obtaining a certificate is a master's degree and 5 years of experience in the field $[4,5]$. Despite the existing legislation, there is no certified educational program in Slovakia yet, nor any similar one with a foreign one. Following the research results, within the framework of education, we recommend that legislators also implement the Department of Wound Management at the level of advanced practice in nursing among educational departments. It is worth adopting such an educational certified model of the ZWM-KAMMERLANDER-WFI Wound management academy following the example of Switzerland, Germany and Austria, or the European Wound Management Association (EWMA), which provide documents containing minimum educational standards (curricula) for certification and specialization study in wound management programs $[10,11]$. According to the current legislation, which determines the scope of nursing practice provided by the nurse independently, separately on the basis of the doctor's indication, and in cooperation with the doctor, the nurse's competencies in wound management is to independently assess and treat skin integrity disorders [2]. From our point of view certified nurses can significantly influence the management of wound healing. We found out that this issue was addressed by management in the institutionalized area of health care in Slovakia, where in 2014 in NUSCH, a.s. was launched a program for the prevention of pressure ulcers unique of its kind, which is focused on monitoring the risk factors for bedsores, their prevention and subsequent treatment by the method of wet healing. It includes a trained special team of nurses, whose task are activities aimed at training and directing nurses to identify chronic wounds and pressure ulcers, their accurate documentation and determination of appropriate treatment, including continuous control of wound healing in the context of multidisciplinary cooperation, so-called "Morning team" [12]. The result of the work of the "Morning team" according to the statistical comparison of 2015 and 2016 , recorded a decrease in sacral pressure ulcers by $17 \%$, in the header by $10 \%$ and in the heels by $41 \%$. Of the total number of pressure ulcers, the largest group was pressure ulcers II degree [13].

We also want to point out that even in long-term care facilities like nursing homes, they implemented in the organizational scheme of the workplace "decubitus nurses", which became the mainstays for long-term and ongoing evaluation of the quality of wound and pressure ulcer treatment. The ulcer nurse assesses all wounds and reviews the pressure ulcer prevention plan. They established the nurse admitting patients to a facility that will critically assess the risk of pressure ulcers based on the Norton scale. She records all findings on a form with an individual pressure ulcer prevention plan, if she finds a mild or high risk of pressure ulcers, prescribes a shortened positioning interval, air baths, insertion of a permanent urinary catheter, active compressor pad, blood protein collection, albumin, iron, and if necessary she will provide nutritional support. The authors point out that they also use the so-called positioning clock [14]. Another interesting initiative is the creation of a Center for the Treatment of Chronic Open Wounds, modeled on the Copenhagen Wound Center - the Danish Wound Treatment Center, or the establishment of mobile infirmaries with complete equipment and training in chronic wound care for immobile patients with infected open wounds [11].

In Austria, they recorded disproportionately large quality differences in the treatment and care of patients with chronic wounds, so in 2012-2017 they introduced an expert standard for quality development called "Treatment of people with chronic wounds". Departments that achieved a high audit score were awarded a Wound Management Certificate. The evaluation focuses on identifying the wound situation, clearly 
identifying the nursing and treatment plan, coordinating interpersonal process management, performing phase-oriented wound care, counseling and training patients, and evaluating overall interventions. The output of the certification was structural and process indicators, especially in the education of nursing staff in wound management, intensification of patient education, and the creation and implementation of standardized documentation [15]. A prerequisite for effective wound management is the essential identification and assessment of wound etiology, and adherence to the prescribed standardized diagnostic and therapeutic procedure.

In the intentions of our findings according to the set research goals, we consider a significant and substantial application of a nurse with advanced experience with a certificate in wound management in institutionalized and community health care for long-term patients, postoperative conditions and their complications and other problems related to chronic diseases. We came to the coclusion that the application of certified activities for nurses in order to provide independent nursing practice on the basis of applicable legislation within the scope of its competencies in wound management is possible based on the definition of territorial scope, which is based on a minimum network of health care providers developed by the self-governing region [16-18]. It is important to choose appropriate marketing strategies and promotion of services in the management of chronic wounds.

\section{Conclusions}

Chronic wounds and their problems are highly topical due to unfavorable statistics of long-term patients with chronic diseases and their complications, which include chronic wounds [19]. Our findings show that the analysis of data expresses a positive perception of management in the context of the application of a nurse with advanced experience in wound management and the creation of a job position for such a nurse. Respondents are similarly positive about their cooperation with a nurse with advanced experience in wound management in consultations. Based on the results of the work, we recommend creating a positive image of a nurse with advanced experience in the management of chronic wounds with a strong emphasis on autonomy, independence and responsibility. It is important to apply education according to current legislation, to implement a certified nurse in the field of wound management in practice, and increase autonomous competencies in the context of advanced practice in nursing in cooperation with the Ministry of Health and health insurance companies in contracting nursing services. As part of their application, it is important to support the licensing of nurses in the independent practice under current legislation [17] and to establish good cooperation with the self-governing region, general practitioners, specialist doctors and management in the provision of institutionalized and community health care.

\section{References}

1. Grray, TA, Rhodes, S., Atkinson, RA, Rothwell, K., Wilson, P., Dumville, JC, Cullum, NA. Opportunities for better value wound care: a multiservice, cross-sectional survey of complex wounds and their care in a UK community population. In BMJ Open, 8(3):e019440 doi: 10.1136/bmjopen-2017-019440.

2. Decree of the National Council of the Slovak Republic No. 95/2018 Coll.

3. Wound, ostomy and continence certification board (2019) [online]. [cit. 2020-05-01]. Avaliable at: https://www.wocncb.org/.

4. Royal colledge of Surgeons Ireland (2019) Post graduate diploma in Nursing/MSc in Wound Management \&Tissue Viability. [online]. [cit. 2020-05-01]. Avaliable at: https://www.rcsi.com/dublin.

5. Cardiff University (2019) Wound Healing [online]. [cit. 2020-05-01]. Avaliable at: https://www.cardiff.ac.uk/study/ postgraduate/taught/courses/standalone-modules/wound-healing-foundation-modules-he-level-6-tissue-viability.

6. Grešš Halász., B., Tkáčová, L', Magurová, D. Advanced nursing practice. Prešov: Grešš Halasz, p. 160. ISBN 978-80-570-0922-1.

7. Corbett, LQ. Wound Care Nursing: professional issue and opportunities. In Advances in Wound Care 1(5):189-193. ISSN 2162-1934.

8. Action of the Ministry of Health of the Slovak Republic of 12 December 2019 no. 09796-2019-OL amending the Decree of the Ministry of Health of the Slovak Republic of 17 September 2010 no. 12422/2010-OL laying down minimum standards for specialization study programs, minimum standards for certification study programs and minimum standards for continuing education study programs and their structure, as amended.

9. Regulation of the Government of the Slovak Republic no. 296/2010 Coll. on professional competence for the exercise of the medical profession, the method of further education of medical staff, the system of specialized departments and the system of certified work activities4. Decree of the Ministry of Health of Slovak Republic No. 34/2018 Coll.

10. Grešš Halász, B. et al. Slovak Society for the treatment of open wounds (SSOOR) [online]. [cit. 2020-01-01]. Dostupné na internete: http://www.sdia.sk/o-nas-aktuality/40/slovenska-spolocnost-pre-osetrovanie-otvorenych-ran-ssoor/.

11. Grešš Halász, B., Lizáková, L., Rošák, M. Manažment chronických rán. In Quo vadis zdravotníctvo IV. Nové trendy v zdravotníckych vedách (electronic): Zborník (Proceedings of conference) z medzinárodnej vedeckej konferencie, Prešov: Prešovská univerzita v Prešove, 2019, s. 49-61, ISBN 978-80-555-2311-8, Dostupné na: http://www.pulib.sk/web/pdf/web/ viewer.html?file=/web/kniznica/elpub/dokument/Mikulakova3/subor/9788055523118oprava.pdf. 
12. NÚSCH a.s. National Institute of Heart Disease: What is pressure ulcers? How to prevent its occurrence? What is home care? How to position correctly? [online]. [cit. 2020-05-01]. Avaliable at: https://www.nusch.sk/sk/818/co-je-to-dekubitako-predist-jeho-vzniku-aka-je-domaca-starostlivost-ako-spravne-polohovat.

13. Šuttová, G. Prevention of pressure ulcers and care of chronic wounds in NUSCH, a.s. Wound team [presentation]. In Congress of the Slovak Medical Society and the Slovak Society for Wound Healing (SSPLR) with international participation, 2017.

14. Kličová, M., Fabiánová, Ž. Our practical experience with the treatment of pressure ulcers. In Sestra 18 (9-10):8-10. ISSN 1335-9444.

15. Kozoň, V. Treatment of patients with wounds in AKH - medical university campus Vienna, certification and postgraduate training in wound management. [presentation]. In Congress of the Slovak Medical Society and the Slovak Society for Wound Healing (SSPLR) with international participation.

16. Act of the National Council of the Slovak Republic no. 576/2004 Coll. on health care, services related to the provision of health care.

17. Act of the National Council of the Slovak Republic no. 578/2004 Coll. on health care providers, health care workers, professional organizations in health care.

18. Act no. 455/1991 Coll. - Trade Licensing Act.

19. Belovičová, M., Vansáč, P. Selected aspects of medical and social care for long-term ill persons. Towarzystwo Slowaków w Polsce, Kraków, 2019, 153 p. ISBN 978-83-811110-9-6.

Дата надходження рукопису до редакції: 17.06.2020 p.

Aim: To map the interest in further education in wound management in the context of advanced nursing practice, to find out whether a nurses with certification in chronic wound management according to current legislation is desirable from the point of view of management for job creation, and to find out how management perceives legislative and working conditions of application for the performance of independent practice in the profession of nurse in the management of chronic wounds.

Design. Quantitative exploratory descriprive.

Participants. 48 nurses with advanced experience working with patients with chronic, non-healing or difficult to heal wounds in the position of manager working in the institutionalized or community area of healthcare.

Methods. Questionnaire with own structure. Data processing by descriptive and inductive statistics program SPSS 25.0.

Results. The results represent a positive level of perception of the enforcement of a nurse with advanced experience with a certificate in the management of chronic wounds to create a job position. A similar result was achieved in the perception of cooperation with a nurse with advanced experience with a certificate in the management of chronic wounds in the context of consultations. We found out that a higher level of perception was among respondents working in the community area in homecare, who are licensed to perform the duties of a professional representative.

Conclusions. The self-concept of a nurse with advanced experience in the field of chronic wound management shows a positive evaluation among managers in the community area of care working in ADOS. The results of the research show the need for visibility of a certified nurse in the management of chronic wounds and its implementation and application in practice.

Key words: certificate in wound management, education, advanced practice of nurses, working conditions.

Мета: скласти карту інтересів щодо подальшого навчання по лікуванню ран в контексті передової практики сестринської справи, з’ясувати, чи бажаним є для медсестер сертифікація лікування хронічних ран, відповідно до чинного законодавства, з точки зору керівництва для створення робочого місця. 3'ясувати, як керівництво сприймає законодавчі та робочі умови для виконання незалежної практики в професії медсестри при лікуванні хронічних ран.

Матеріали та методи. Дизайн дослідження - кількісно-дослідницький опис. Група дослідження: 48 медсестер 3 великим додатковим досвідом роботи з пацієнтами з хронічними ранами, на посаді менеджера, що працює в установах охорони здоров'я або громадах. Використовувся метод анкетування з використанням власної оригінальної анкети. Обробка даних за допомогою програми дескриптивної і індуктивної статистики SPSS 25.0.

Результати. Аналіз результатів показав позитивний рівень сприйняття менеджерами появи медсестри 3 додаткові досвідом і сертифікатом в області лікування хронічних ран для створення даної посади. Аналогічний результат був досягнутий в сприйнятті співпраці з медсестрою з великим досвідом роботи 3 сертифікатом лікування хронічних ран в контексті консультацій. Ми виявили вищий рівень сприйняття серед респондентів, які працюють в співтоваристві в сфері догляду на дому (ADOS), які мають ліцензію на виконання функцій професійного представника.

Висновки. Самооцінка медсестри з додатковим досвідом лікування хронічних ран показує позитивну оцінку у менеджерів по догляду на дому, що працюють в ADOS. Результати дослідження показують на необхідність залучення більшої уваги до сертифікації медсестер в веденні хронічних ран.

Ключові слова: сертифікат з лікування ран, освіта, медсестри з великим досвідом роботи, умови праці. 
Конфлікт інтересів: відсутній.

Conflicts of interest: authors have no conflicts of interest to declare.

\section{Відомості про авторів}

Rónayová Ivana - PhDr., St. Elizabeth University of Health and Social Sciences, Bratislava - doctoral study. ivana.ronayova@gmail.com.

Grešš Halász Beáta - PhD., PhDr., University of Prešov, Faculty of Health Sciences, Department of Nursing. beata.gress.halasz@unipo.sk. 